\title{
Post-testicular sperm maturation and identification of an epididymal protein in the Japanese quail (Coturnix coturnix japonica)
}

\author{
Brett Nixon, Katherine A Ewen, Klara M Krivanek, John Clulow, Grahame Kidd², \\ Heath Ecroyd ${ }^{1}$ and Russell C Jones \\ Reproductive Science Group, Discipline of Biological Sciences, School of Environmental and Life Sciences, \\ University of Newcastle, University Drive, Callaghan, New South Wales 2308, Australia, ${ }^{1}$ School of Biological \\ Sciences, Illawarra Health and Medical Research Institute, University of Wollongong, Wollongong, New South Wales \\ 2522, Australia and ${ }^{2}$ Cleveland Clinic Main Campus, Euclid Avenue, Cleveland, Ohio 44195, USA
}

Correspondence should be addressed to B Nixon; Email: Brett.Nixon@newcastle.edu.au

\begin{abstract}
The role of the avian epididymis in post-testicular development and capacitation was examined to assess whether avian spermatozoa undergo any processes similar to those characteristic of mammalian sperm development. We found no evidence of a need for quail sperm to undergo capacitation and $\mathbf{9 0} \%$ of testicular sperm could bind to a perivitelline membrane and acrosome react. However, computer-assisted sperm analysis showed that $20 \%$ of testicular sperm from the quail were capable of movement and only about $12 \%$ of the motile sperm would have a curvilinear velocity greater than the mean for sperm from the distal epididymis. Nevertheless, epididymal transit was associated with increases in mean sperm velocity and the proportion of motile sperm. Together, these findings explain why earlier workers have achieved some fertilizations following inseminations of testicular spermatozoa and also demonstrate the need for some epididymal maturation of avian spermatozoa. Analysis of the electrophoretic profile of quail epididymal luminal proteins revealed that only one major protein $(\sim 16 \mathrm{kDa})$ is secreted by the epididymis and it was virtually the only protein secreted by the ipsilateral epididymis following unilateral orchidectomy. Mass spectrometry showed that this protein is hemoglobin; this finding was confirmed using anti-hemoglobin antibodies. It is suggested that hemoglobin may support sperm metabolism in the quail epididymis, aid in motility, and/or serve as an antioxidant.
\end{abstract}

Reproduction (2014) 147 265-277

\section{Introduction}

This report examines how the avian epididymis differs from the mammalian epididymis in determining sperm development and fertilization. Although it is well established that mammalian sperm must undergo maturation in the epididymis to gain the potential to fertilize an ovum (Bedford 1967, Orgebin-Crist 1967, Sonnenberg-Riethmacher et al. 1996), and then spend time in the female tract in order to capacitate before they can actually fertilize an ovum (Austin 1951, Chang 1951), the need for extra-testicular sperm maturation in birds is contentious. In mammals, sperm maturation involves structural modifications, changes in the lipid and protein composition of the plasmalemma (Jones 1989, 1998), and development of a characteristic pattern of motility (Morton et al. 1978, Jones \& Murdoch 1996). The maturation process requires proteins synthesized by the epididymal epithelium (Orgebin-Crist \& Jahad 1978, Dacheux et al. 2009, 2012) and the incorporation of these proteins into the sperm plasmalemma (Rankin et al. 1992). Capacitation involves modification of the lipid composition and permeability of the sperm plasmalemma (Davis et al. 1979, Davis 1981), loss of decapacitation factors (Fraser et al. 1990, Gibbons et al. 2005, Nixon et al. 2006), and the initiation of complex signaling pathways (Visconti et al. 1995a, 1995b), which are routinely assessed by determining tyrosine phosphorylation of sperm proteins (Asquith et al. 2004).

Bedford et al. (Esponda \& Bedford 1985, Morris et al. 1987) implicated epididymal secretions in post-testicular sperm maturation. However, the only studies directly testing the development of fertilizing capacity have been on the domestic fowl and Japanese quail. These studies found that subjective scores of the percentage of motile sperm increase during epididymal transit, indicating that some post-testicular sperm maturation occurs in birds (Munro 1938, Clulow \& Jones 1982, Ahammad et al. 2011a, 2011b). Studies involving insemination into the vagina confirmed the need for some post-testicular 
sperm maturation (Munro 1938, Howarth 1983). However, the status of testicular sperm has not been satisfactorily resolved. While Howarth (1983) achieved no fertilizations following vaginal insemination of testicular sperm, Munro (1938) obtained a fertilization rate of about $4 \%$, indicating that some testicular sperm had the capacity to ascend the female tract and fertilize eggs. Indeed, when the vagina was by-passed by intramagnal insemination, Howarth (1983) obtained fertilization rates with testicular sperm that were as high as epididymal and ejaculated sperm. As these discrepancies indicate a poor understanding of the role of the avian epididymis in the development of sperm motility, we have used a modern objective method (computer-assisted sperm analysis (CASA)) to examine the motility of sperm from the testis and epididymis of the Japanese quail.

There have been several studies on sperm capacitation in birds, but a process like capacitation in mammals has not been detected (Howarth 1970, Howarth \& Palmer 1972). Studies in vitro indicated that fowl and turkey sperm do not require a period of capacitation in the female tract in order to fertilize an ovum (Howarth 1970, Howarth \& Palmer 1972) and that the acrosome reaction may be rapidly induced after incubation of fowl sperm in vitro in the presence of the inner perivitelline membrane of the oocyte and extracellular calcium (Horrocks et al. 2000, Lemoine et al. 2008). However, since Lemoine et al. (2009) found that protein kinase A was involved in stimulating the acrosome reaction and phosphorylation of the effector proteins in fowl spermatozoa (Lemoine et al. 2009) and this pathway is assayed to assess capacitation in mammals, we have used the same assay to assess the need for capacitation in quail sperm.

Apart from our conference report on the Japanese quail (Jones et al. 2003), epididymal proteins and changes to the sperm membrane of birds have only been studied in the domestic fowl. Esponda \& Bedford (1985) showed that a subset of epididymal proteins bind to the sperm surface and remain adherent even after prolonged incubation in the female reproductive tract (Esponda \& Bedford 1985, Morris et al. 1987). Also, Ahammad et al. (2011b) demonstrated a correlation between epididymal passage and an increase in the capacity of fowl sperm to bind to the epithelium of the female reproductive ducts. However, there are no welldocumented studies of the occurrence of avian epididymal proteins. Consequently, we report a study of the quail epididymal proteome and identify the only protein that is dependent on the testis for its secretion into the lumen of the duct.

\section{Materials and methods}

\section{Chemicals and reagents}

Unless otherwise specified, chemical reagents were obtained from Sigma and were of molecular or research grade.
Polyclonal antibodies raised against a synthetic peptide mapping to an internal region of hemoglobin $\alpha$ chain (HBA) of mouse origin were purchased from Santa Cruz Biotechnology, Inc. (catalogue \#sc-31332). HRP and FITCconjugated secondary antibodies were from Sigma.

\section{Animals}

All experimental procedures were conducted with the approval of the University of Newcastle's Animal Care and Ethics Committee (ACEC). Sexually mature male Japanese quail (Coturnix coturnix japonica) were obtained from a breeding colony at Redgate Farm (Seaham, NSW, Australia). Adult ( $>8$ weeks old) Swiss mice were obtained from a breeding colony held at the University of Newcastle Central Animal House. All animals were maintained in accordance with the recommendations prescribed by the ACEC. Both quail and mice were housed under a controlled lighting regime $(16 \mathrm{~h}$ light:8 $\mathrm{h}$ darkness) at $21-22^{\circ} \mathrm{C}$ and supplied with food and water ad libitum. Unless otherwise stated, animals were killed by $\mathrm{CO}_{2}$ inhalation.

\section{Assessment of quail sperm motility}

Quail sperm motility was assessed using the Hamilton Thorne CASA IVOS II system (Hamilton Thorne, Inc., Beverly, MA, USA). Spermatozoa were recovered from different regions of the male reproductive tract; diluted into Biggers, Whitten, and Whittingham media (BWW; Biggers et al. 1971); and placed onto 2X-CEL Sperm Analysis Chamber slides (Hamilton Thorne, Inc.). The sperm were viewed under a Zeiss Axiovert S 100 inverted microscope in dark field at $400 \times$ magnification and recorded on a JVC S-VHS HR-S5700AM 6 head video recorder, after which the motility was analyzed using CASA Software (Hamilton Thorne).

\section{Sperm binding assay}

In order to assess the functionality of quail spermatozoa isolated from different regions of the reproductive tract, they were incubated with the inner perivitelline layer of preovulated ova (PVM). For this purpose, quail hens were killed and their reproductive tract dissected. The largest primary follicle present in the ovary was removed and the granulosa layer, including granulosa cells, the inner perivitelline layer, and the basal laminar, was isolated according to the procedure of Mori \& Kantou (1987). The inner perivitelline layer was then isolated according to the method of Kuroki \& Mori (1995). Briefly, the granulosa layer was placed in distilled water to allow the granulosa cells to swell and lyse, and this suspension was then washed with a stream of water from a Pasteur pipette to remove granulosa and basal lamina cells. The inner perivitelline layer was recovered and laid onto a glass microscope slide before being incubated with spermatozoa $\left(\sim 50000\right.$ cells) for $30 \mathrm{~min}$ at $37^{\circ} \mathrm{C}$ in $5 \% \mathrm{CO}_{2}$. The inner perivitelline layer preparation was then washed to remove nonspecifically bound and loosely adherent spermatozoa before being viewed using a Zeiss Axiovert S100 inverted phasecontrast microscope. The number of bound viable (motile) 
spermatozoa was assessed over a $600 \mu \mathrm{m}$ section of the inner perivitelline layer.

\section{Assessment of sperm acrosome reaction}

A preparation of isolated PVM was homogenized in a glass homogenizer before being incubated with spermatozoa for $30 \mathrm{~min}$ at $37^{\circ} \mathrm{C}$. After incubation, the spermatozoa were subjected to a hypo-osmotic swelling test (Nixon et al. 2006) to determine the percentage of viable sperm in each population. The cells were pelleted by gentle centrifugation $(1000 \mathrm{~g}$, $5 \mathrm{~min}$ ) before being resuspended and fixed in ice-cold methanol for $10 \mathrm{~min}$. A $10 \mu \mathrm{l}$ aliquot of this suspension was placed onto a slide, allowed to air-dry, and then incubated with FITCconjugated Arachis hypogaea lectin (PNA). After $15 \mathrm{~min}$, spermatozoa were examined and viable cells (curled tails) were scored ( $>100$ sperm per treatment) as acrosome intact (acrosomal region fluorescently labeled with PNA) or acrosome reacted (complete absence of PNA staining in the acrosomal region).

\section{Quail orchidectomy}

Animals were anesthetized with Halothane and the testes were accessed via an incision in the abdominal wall. Testes were removed after ligation between the testis and epididymis and then the abdominal incision was sutured. The animals were killed 2 weeks after orchidectomy and the epididymal proteins were recovered. In the orchidectomy experiment, epididymal proteins were extracted after flushing the vascular system with saline and shaking minced samples of the ductus epididymidis in Krebs-Ringer phosphate ( $\mathrm{pH} 7.4)$ for $10 \mathrm{~min}$.

\section{Collection of quail epididymal luminal fluid}

Micropuncture samples were collected from the seminiferous tubules, rete testis, and ductus epididymidis of quail anesthetized with 5-sec-butyl-5-ethylthiobarbituric acid (Inactin; Byk Gulden Pharmaceuticals, Konstanz, Germany), and the plasma component, designated as quail epididymal plasma (QEP), was separated from sperm by centrifugation as described by Clulow \& Jones (2004). Alternatively, epididymal luminal fluid was collected by retrograde flushing of the ductus epididymidis with modified BWW media (Biggers et al. 1971) containing $91.5 \mathrm{mM} \mathrm{NaCl}, 4.6 \mathrm{mM} \mathrm{KCl}, 1.7 \mathrm{mM} \mathrm{CaCl} \cdot 2 \mathrm{H}_{2} \mathrm{O}, 1.2 \mathrm{mM}$ $\mathrm{KH}_{2} \mathrm{PO}_{4}, 1.2 \mathrm{mM} \mathrm{MgSO} 4 \cdot 7 \mathrm{H}_{2} \mathrm{O}, 25 \mathrm{mM} \mathrm{NaHCO}, 5.6 \mathrm{mM}$ D-glucose, $0.27 \mathrm{mM}$ sodium pyruvate, $44 \mathrm{mM}$ sodium lactate, $5 \mathrm{U} / \mathrm{ml}$ penicillin, $5 \mu \mathrm{g} / \mathrm{ml}$ streptomycin, $20 \mathrm{mM}$ HEPES buffer, and $3 \mathrm{mg} / \mathrm{ml}$ polyvinyl alcohol. Briefly, the entire epididymal duct was dissected from the quail and the distal papilla of the ductus epididymidis was isolated from surrounding fatty tissue. Care was taken to avoid damage to the regional vasculature and the possibility of blood contamination. A cannula was inserted against the direction of flow, secured with a silk ligature, and connected to a $1 \mathrm{ml}$ syringe preloaded with BWW. A section of tubule from the proximal region of the epididymis was isolated from the remainder of the organ and cut. Luminal fluid was collected into a $1.5 \mathrm{ml}$ tube as it was expelled from the proximal end of the duct by retrograde perfusion with BWW. Where appropriate, samples were centrifuged immediately after collection $(1000 \mathrm{~g}$, $5 \mathrm{~min})$ to separate QEP and spermatozoa.

\section{Extraction of sperm proteins}

Quail spermatozoa were recovered after centrifugation of epididymal luminal fluid, resuspended in BWW, and gently washed ( $1000 \mathrm{~g}, 5 \mathrm{~min}$ ) to remove non-specifically bound and loosely adherent proteins from the QEP. The washed sperm pellet was resuspended in $10 \mathrm{mM} \mathrm{CHAPS}$ (Research Organics, Cleveland, $\mathrm{OH}, \mathrm{USA}$ ) and incubated on ice for $1 \mathrm{~h}$ with vortexing every $10 \mathrm{~min}$. The cell lysate was centrifuged (10 $000 \mathrm{~g}, 10 \mathrm{~min}$ ) and the supernatant was recovered.

\section{SDS-PAGE}

The concentration of protein in samples was estimated colorimetrically using Coomassie Brilliant Blue R250 (Bradford 1976) or a bicinchoninic acid protein assay kit (Thermo Fisher Scientific, Rockford, IL, USA) in accordance with the manufacturer's recommendations. Equivalent amounts of protein (10 pg for Fig. 4A and $5 \mu \mathrm{g}$ for other studies) were resolved by one-dimensional (1D) SDS-PAGE (Laemmli 1970) and the gels were either stained with Coomassie Blue (Fig. 4B) or silver reagent, or prepared for western blotting.

Two-dimensional (2D) SDS-PAGE was employed as an additional technique for the separation of QEP in preparation for sequencing proteins of interest. For this purpose, aliquots of QEP containing $\sim 100 \mu \mathrm{g}$ protein were precipitated as described previously (Nixon et al. 2002a). To each sample, $1.25 \mu \mathrm{l}$ Pharmalytes (GE Healthcare, Piscataway, NJ, USA), $1.5 \mu \mathrm{l}$ Destreak (GE Healthcare), and trace amounts of bromophenol blue were added and the samples were used to rehydrate immobilized $\mathrm{pH}$ gradient (IPG) gel strips $(\mathrm{pH} 3-10$, $7 \mathrm{~cm}$, nonlinear IPG gels; GE Healthcare) overnight. Isoelectric focusing of the samples was achieved on an IPGphor (GE Healthcare) with the protocol of $300 \mathrm{~V}$ for $0.9 \mathrm{kVh}$ (step and hold), a gradient up to $1000 \mathrm{~V}$ for $3.9 \mathrm{kVh}$, followed by an additional gradient to $8000 \mathrm{~V}$ for $13.5 \mathrm{kVh}$. The sample was then held at $8000 \mathrm{~V}$ for a total $77.7 \mathrm{kVh}$. After focusing, each IPG strip was pre-equilibrated in SDS equilibration buffer (50 mM Tris, $6 \mathrm{M}$ urea, 30\% w/v glycerol, $2 \% \mathrm{w} / \mathrm{v}$ SDS, and trace bromophenol blue) supplemented with $0.5 \% \mathrm{w} / \mathrm{v}$ dithiothreitol (DTT) and 4\% w/v iodoacetamide for $10 \mathrm{~min}$ with constant shaking. The strips were then placed on top of a $10 \% \mathrm{v} / \mathrm{v}$ SDS-PAGE gel and proteins resolved prior to staining with silver reagent or being prepared for western blotting.

\section{Protein identification}

Proteins of interest were carefully excised from 1D and 2D SDS-PAGE gels and sequenced at the Australian Proteome Analysis Facility (APAF Ltd., Macquarie University, Sydney, NSW, Australia) using an electrospray ionization (ESI) mass spectrometry interface. In preparation for sequencing, the gel slices were destained, then reduced (25 mM DTT in $25 \mathrm{mM}$ ammonium bicarbonate), and alkylated (55 $\mathrm{mM}$ iodoacetamide in $25 \mathrm{mM}$ ammonium bicarbonate). The proteins within 
the gel slice then underwent a 16 -h tryptic digest at $37^{\circ} \mathrm{C}$. After digestion, $0.1 \% \mathrm{v} / \mathrm{v}$ trifluoroacetic acid (TFA) was added and the sample was sonicated for $10 \mathrm{~min}$. The resulting digested peptides were separated by nano-liquid chromatography (LC) using a CapLC system (Agilent 1100 Series, Agilent Technologies, Böblingen, Germany). Samples were injected onto a peptide trap (Michrome Peptide Captrap Inc., Auburn, CA, USA) for pre-concentration and desalted with $0.1 \% \mathrm{v} / \mathrm{v}$ TFA at $10 \mu \mathrm{l} / \mathrm{min}$. The peptide trap was then switched into line with the analytical column containing $\mathrm{C} 18$ reverse-phase silica (SGE ProteCol C18, 300A, $3 \mu \mathrm{m} \times 150 \mu \mathrm{m} \times 10 \mathrm{~cm}$ ).

Peptides were eluted from the column using a linear solvent gradient, with steps, from $\mathrm{H}_{2} \mathrm{O}: \mathrm{CH}_{3} \mathrm{CN}(95: 5+0.1 \% \mathrm{v} / \mathrm{v}$ formic acid) to $\mathrm{H}_{2} \mathrm{O}: \mathrm{CH}_{3} \mathrm{CN}(20: 80+0.1 \% \mathrm{v} / \mathrm{v}$ formic acid) at $500 \mathrm{nl} / \mathrm{min}$ over a 130-min period. The LC eluent was subjected to positive ion nanoflow electrospray analysis on an Applied Biosystems QSTAR XL mass spectrometer (Life Technologies). The QSTAR was operated in an information-dependent acquisition (IDA) mode. In IDA mode, a time-of-flight mass spectrometry survey scan was acquired ( $\mathrm{m} / \mathrm{z} 380-1600,0.5 \mathrm{~s})$, with the three largest multiply charged ions (counts $>70$ ) in the survey scan sequentially subjected to MS/MS analysis. MS/MS spectra were accumulated for $2 \mathrm{~s}$ ( $\mathrm{m} / \mathrm{z}$ 100-1600).

The LC-MS/MS data were searched using Mascot (Matrix Science, London, UK). Mascot was used to search entries for species $C$. coturnix japonica in the SwissProt protein database with the following search parameters: maximum of one missed trypsin cleavage, cysteine carbamidomethylation, methionine oxidation, and a maximum 0.2 Da error tolerance in both the MS and MS/MS data. High-confidence positive identifications were based on a minimum of two matching peptides and were confirmed or qualified by operator inspection of the spectra and search results.

\section{Immunoblotting}

QEP proteins separated on either 1D or 2D SDS-PAGE gels were transferred onto nitrocellulose membranes (Hybond C-extra; GE Healthcare) by western blotting (Towbin et al. 1979) at a constant current of $300 \mathrm{~mA}$ for $1 \mathrm{~h}$. Membranes were blocked overnight at $4{ }^{\circ} \mathrm{C}$ in Tris-buffered saline (TBS) containing $5 \% \mathrm{w} / \mathrm{v}$ skimmed milk powder. After rinsing with TBS containing $0.01 \% \mathrm{v} / \mathrm{v}$ Tween 20 (TBST), membranes were incubated sequentially with primary antibody at $4{ }^{\circ} \mathrm{C}$ overnight and an appropriate HRP-conjugated secondary antibody for $1 \mathrm{~h}$ at room temperature. Following three washes in TBST, labeled proteins were detected using enhanced chemiluminescence reagents.

\section{Immunohistochemical localization}

Epididymides were recovered from adult male quails and mice at autopsy, dissected free of fat and overlying connective tissue, immediately fixed in $10 \% \mathrm{v} / \mathrm{v}$ formalin, embedded in paraffin, and cut into $5 \mu \mathrm{m}$ sections. Following de-waxing and rehydration, antigen retrieval was performed by microwaving $(500 \mathrm{~W})$ the sections for $20 \mathrm{~min}$ in citrate buffer $(10 \mathrm{mM}$ trisodium citrate and $4.4 \mathrm{mM} \mathrm{HCl}, \mathrm{pH}$ 6.0). All subsequent incubations were performed at $37^{\circ} \mathrm{C}$ in a humid chamber, and all antibody dilutions and washes were conducted in PBS.
Non-specific antibody binding was blocked by incubation of sections in $10 \% \mathrm{v} / \mathrm{v}$ normal goat serum supplemented with $3 \%$ $w / v$ BSA in PBS. Slides were washed and incubated sequentially in primary antibody (diluted 1:100) and an appropriate FITC-conjugated secondary antibody (diluted 1:300). After washing, the sections were counterstained with $10 \mu \mathrm{g} / \mathrm{ml}$ propidium iodide, a nuclear dye included to aid morphological assessment. Slides were mounted in antifade reagent $(13 \% \mathrm{v} / \mathrm{v}$ Mowiol 4-88, 33\% v/v glycerol, $66 \mathrm{mM}$ Tris ( $\mathrm{pH}$ 8.5), 2.5\% v/v 1,4 diazabicyclo-[2.2.2] octane), and viewed using a confocal microscope (Carl Zeiss Laser Scanning Microscope 510, Thornwood, NY, USA). Negative controls in which the primary antibody was substituted with PBS were included in immunohistochemical localization studies.

\section{Statistical analysis}

All experiments were replicated with material collected from at least three different animals and the graphical data presented as means and S.E.M. Or S.D. as indicated, the variances being calculated as the variance between animals. Statistical significance was determined by ANOVAs.

\section{Results}

\section{Sperm motility}

Approximately $20 \%$ of testicular sperm from the quail were capable of movement (Fig. 1). Coinciding with their
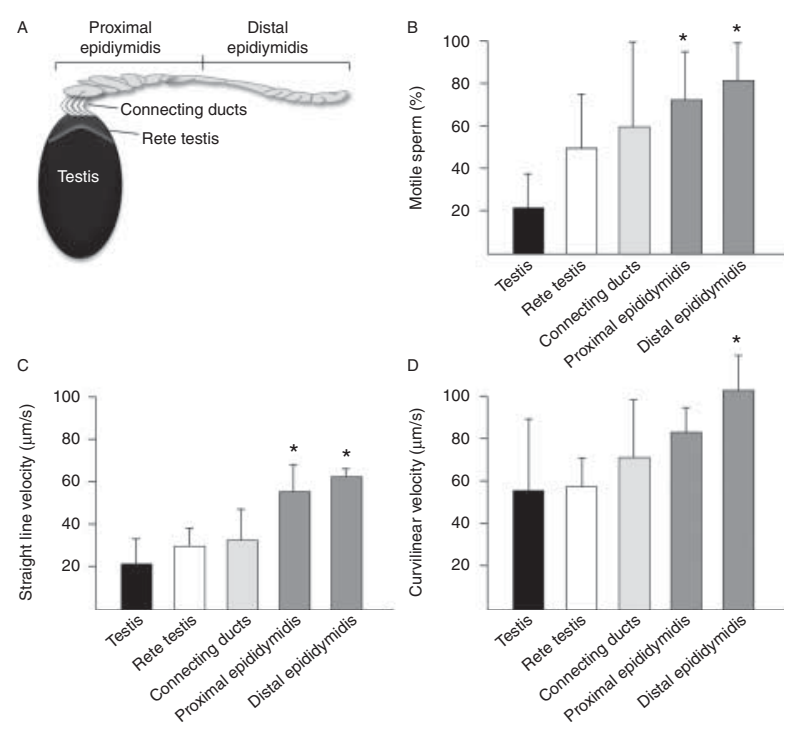

Figure 1 Examination of quail sperm motility. (A) Quail spermatozoa were isolated from the seminiferous tubules of the testes, rete testes, connecting ductules, proximal ductus epididymidis, and distal ductus epididymidis as described in the Materials and methods section. These sperm were diluted into BWW and immediately placed onto chamber slides before being viewed under a Zeiss Axiovert S 100 inverted microscope in dark field at $400 \times$ magnification. The cells were recorded and their motility analyzed for (B) percentage motile, (C) straight-line velocity, and (D) curvilinear velocity using a computerassisted sperm analysis system (Hamilton Thorne, Inc.). Data from three independent experiments are presented as mean \pm s.D. ${ }^{*} P<0.05$. 
entry into the ductus epididymidis, the potential for motility greatly increased and continued to increase to the distal end of the duct where a mean of $>80 \%$ were capable of movement. Further, both the straight-line and curvilinear velocity of the spermatozoa increased $(P<0.05)$ along the ductus epididymidis. It is noteworthy that the s.D.s for the mean velocities of testicular sperm are high, a consequence of some values being higher than for sperm from the distal epididymis. In order to gauge their potential to achieve fertilization following artificial insemination, we estimated (assuming that the values for curvilinear velocity are normally distributed) that about $12 \%$ of the motile sperm from the testis would have a curvilinear velocity greater than the mean for sperm from the distal epididymis. That is, the upper $76 \%$ fiducial limit for the distribution of testicular sperm is mean + S.D. $\times$ (standard normal deviate at $P$ value of 2.4). This equates to $60.1+29.8 \times(1.175)=95.1$, which is similar to the mean for sperm from the distal epididymis (95.6).

\section{Capacitation}

We next examined whether exposure of quail spermatozoa to the epididymal lumen enables them to capacitate, undergo an acrosome reaction, and bind to an oocyte. Capacitation was assessed by determining the ability of quail spermatozoa to undergo tyrosine phosphorylation, an important hallmark of the capacitation process in mammals. In contrast to mouse and human spermatozoa that were employed as positive controls, we saw no evidence for an increase in the ability of quail spermatozoa to tyrosine phosphorylate under conditions that promote capacitation. Indeed, the use of an immunofluorescence assay revealed no tyrosine phosphorylation in populations of quail sperm recovered from any region of the male reproductive tract (Fig. 2A). A more sensitive immunoblot analysis revealed a modest level of tyrosine phosphorylation labeling of quail sperm proteins ranging in molecular weight from $\sim 40-100 \mathrm{kDa}$ (Fig. 2B). However, neither the profile nor the amount of tyrosine phosphorylation labeling was
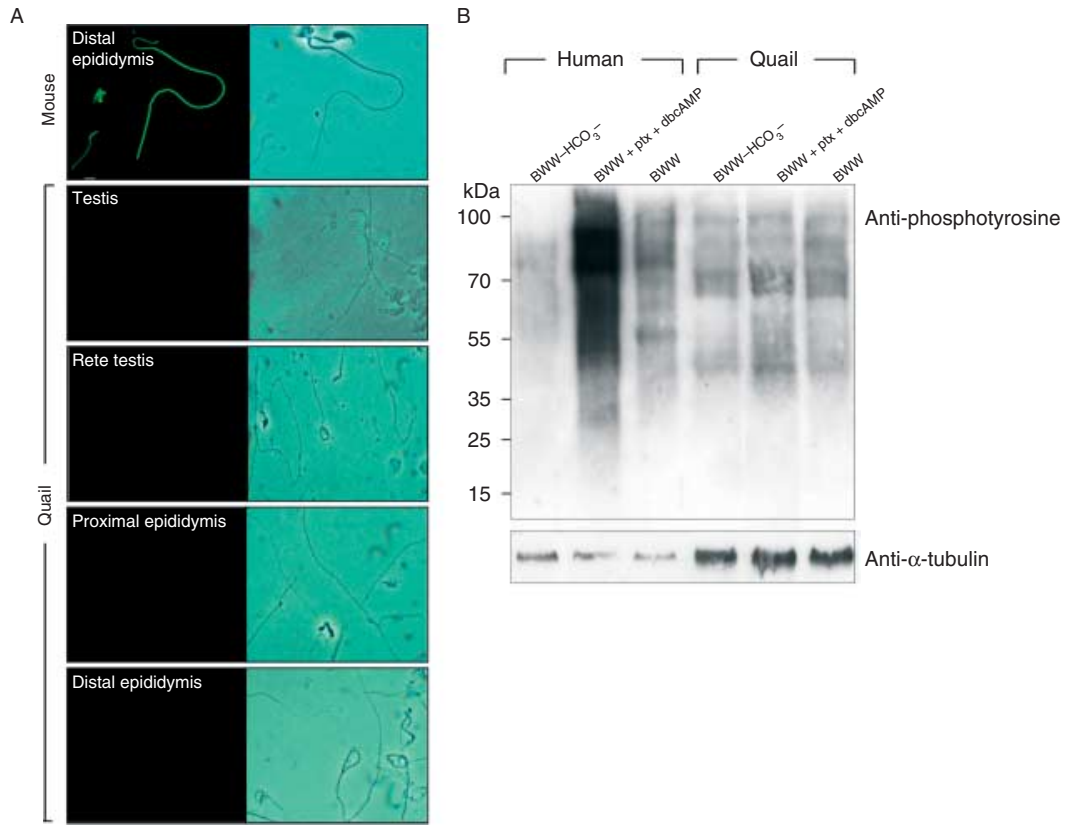

Figure 2 Assessment of the ability of quail sperm to undergo protein tyrosine phosphorylate in response to capacitation stimuli. The ability of quail spermatozoa to capacitate in response to incubation conditions that have been optimized to promote mammalian sperm capacitation was assessed by (A) immunocytochemical and (B) immunoblotting analysis of phosphotyrosine expression. (A) Quail sperm isolated from the testes, rete testes, proximal ductus epididymidis, and distal ductus epididymidis were incubated for 90 min in BWW media supplemented with a phosphodiesterase inhibitor (ptx) and membrane-permeable cAMP analog (dbcAMP) before being fixed in 1\% paraformaldehyde, settled onto poly-L-lysine-coated slides, and permeabilized with $0.2 \% \mathrm{v} / \mathrm{v}$ Triton X-100. The sperm were then sequentially labeled with anti-phosphotyrosine and an appropriate FITCconjugated secondary antibody and viewed by fluorescence microscopy. Despite the failure of these conditions to produce detectable levels of tyrosine phosphorylation in quail spermatozoa from any regions of the male reproductive system, they readily promoted strong tyrosine phosphorylation in mouse (upper panel) and human spermatozoa (data not shown). (B) The ability to promote tyrosine phosphorylation in quail spermatozoa was also examined by immunoblotting. For this purpose, populations of quail spermatozoa from the distal ductus epididymidis were incubated under conditions identical to those described above, in addition to media prepared in the absence of bicarbonate (BWW-HCO ${ }_{3}{ }^{-}$) and non-supplemented media (BWW). The cells were then lysed in SDS extraction buffer and a total of $5 \mu \mathrm{g}$ were resolved by SDS-PAGE and prepared for immunoblotting with anti-phosphotyrosine antibodies. Membranes were then stripped and re-probed with anti- $\alpha$-tubulin to ensure equivalent protein was loaded into each lane. Cell lysates prepared from human and mouse (data not shown) spermatozoa incubated under identical conditions were included as controls in this experiment. 
dramatically influenced by the site of sperm recovery (data not shown), or the inclusion of pharmacological agents (pentoxifylline and dibutyryl cAMP) that have been shown to drive the capacitation of mammalian spermatozoa (Fig. 2B).

\section{Binding to native PVM and induction of acrosomal exocytosis}

A relatively high number of testicular spermatozoa possessed the ability to bind to a preparation of the native PVM and there was no significant increase related to the transit of sperm along the ductus epididymidis (Fig. 3A). Similarly, $>90 \%$ of testicular spermatozoa were capable of completing a PVM-induced acrosome reaction and again this number did not increase along the epididymis (Fig. 3B).

\section{Proteins in quail reproductive ducts}

Figure 4A shows 1D SDS-PAGE gels of the proteins in the plasma component of micropuncture samples of luminal fluids from the seminiferous tubules, rete testis, and proximal, mid, and distal ductus epididymidis of the quail. A complex profile of more than 22 predominant protein bands, ranging in molecular weight from $\sim 10$ to $>100 \mathrm{kDa}$, was present. Comparison of the electrophoretic profiles revealed that the majority of proteins originate as secretions of the seminiferous tubules. A subset of the proteins was apparently reabsorbed in the ductuli efferentes and the concentration of others is altered between the rete testis and ductus epididymis. However, a predominant protein(s) of $\sim 16 \mathrm{kDa}$ was detected that appeared to be secreted into the ductus epididymidis. This interpretation is consistent with the demonstration that unilateral orchidectomy, and hence removal of the luminal connection between the testis and the ductus epididymidis resulted in the disappearance of all but the $16 \mathrm{kDa}$ protein from QEP (Fig. 4B) in the ipsilateral duct. Furthermore, this protein was not detected in QEP sampled from bilateral orchidectomized quails, indicating that its secretion is dependent on the testis (Fig. 4B).

Separation of QEP under non-reducing conditions produced a unique profile of proteins and importantly the $16 \mathrm{kDa}$ band was not detected under these conditions (Fig. 5A), thus raising the possibility that it is part of a larger (multimeric) protein complex cross-linked via disulfide bridges. In addition, the $16 \mathrm{kDa}$ protein was not detected in lysates prepared from spermatozoa sampled from the ductus epididymidis (Fig. 5A), suggesting that it does not form stable interactions with these cells.

As a preliminary step toward identification of the $16 \mathrm{kDa}$ protein, QEP was resolved by 2D SDS-PAGE. This revealed many additional proteins (Fig. 5B) and also resolved the $16 \mathrm{kDa}$ protein into at least two discrete isoforms with isoelectric points of $\sim 6.5-7.5$. Both of these spots, in addition to the corresponding band in the 1D SDS-PAGE gel, were excised and subjected to amino acid sequencing using a 1D nano LC-ESI MS/MS interface.
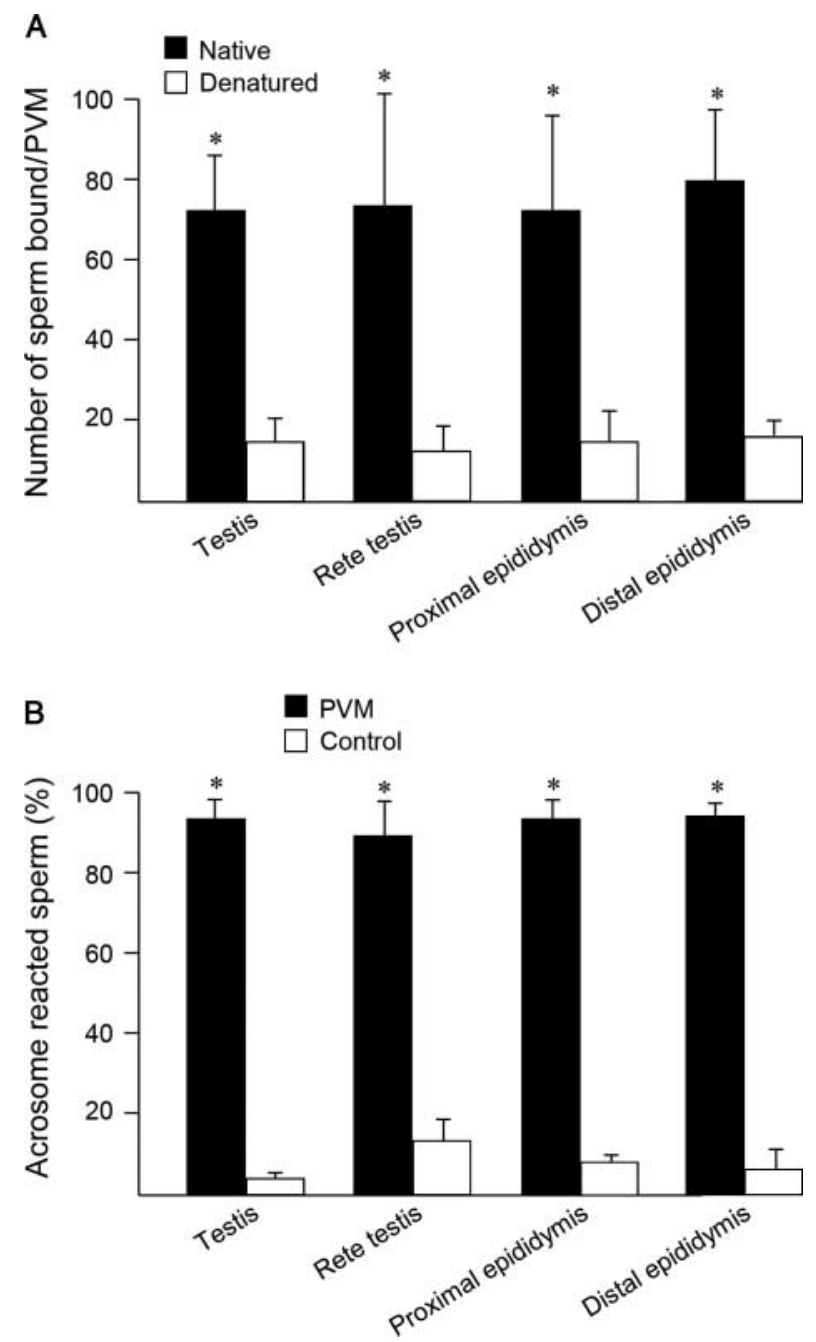

Figure 3 Assessment of the ability of quail sperm to bind PVM and undergo acrosomal exocytosis. Quail spermatozoa from different regions of the reproductive tract were assessed for their ability to (A) adhere to the inner perivitelline layer (PVM) of a primary follicle and (B) undergo an acrosome reaction in response to co-incubation with PVM. (A) For the former studies, spermatozoa were co-incubated with a preparation of either native (black bar) or heat-denatured (white bar) PVM. After washing to remove non-specifically bound and loosely adherent spermatozoa, the PVM was viewed and the number of bound viable (motile) spermatozoa was assessed over a $600 \mu \mathrm{m}$ section of the PVM. (B) Alternatively, spermatozoa were co-incubated with homogenized PVM (black bar) or media alone (control, white bar) before being subjected to a hypo-osmotic swelling test to determine the percentage of viable sperm in each population. The sperm were then fixed and permeabilized in methanol before being labeled with FITCconjugated PNA. A minimum of 100 viable spermatozoa (curled tails) were examined and scored on the basis of their acrosomal status. Both experiments were replicated with independent samples from three quails and data are presented as mean \pm S.E.M. ${ }^{*} P<0.05$. 

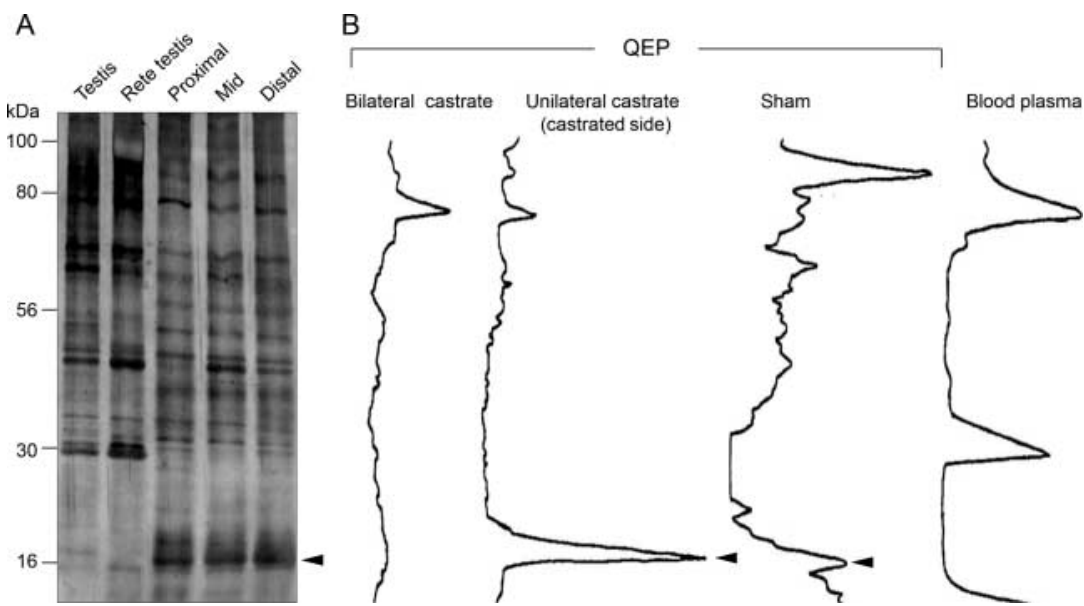

Figure 4 Proteins secreted along the ductus epididymidis of the Japanese quail. (A) Denatured polyacrylamide gel of micropuncture samples of QEP collected from the seminiferous tubules (testis), rete testis, and three regions of the ductus epididymidis (proximal, mid, and distal). The arrowhead indicates the major protein $(\sim 16 \mathrm{kDa})$ detected exclusively in epididymal fluids. (B) Densitometry profiles of QEP obtained from bilaterally castrated, unilaterally castrated (castrated side), and sham quails. A densitometry profile of blood plasma is included as a control. The $\sim 16 \mathrm{kDa}$ protein appears to be the only major protein detected in the epididymal fluid after unilateral orchidectomy and the secretion of this protein is absent following bilateral orchidectomy. Both experiments were replicated with samples from five quails and representative gels and densitometry profiles are shown. Figure adapted from Jones RC, Clulow J, Kidd G, Chaturapanich G, Nixon B \& Dacheux J-L 2003 The avian epididymis: a simple conduit or a sophisticated adaptation? In The Third International Conference on the Epididymis, pp 138-148.

\section{Identification of the 16 kDa quail epididymal secretory protein}

MS sequencing revealed the presence of hemoglobin $\alpha 1$ (HBAA), $\alpha 2$ (HBAD), and $\beta$ (HBB) in the 1D SDS-PAGE gel slices and the two spots excised from 2D SDS-PAGE gels (Table 1). These hemoglobin proteins are of the appropriate molecular weight $(\sim 15.3-16.3 \mathrm{kDa})$ and $\mathrm{pl}$ $(\sim 6.7-7.5)$ for the target proteins (Lee et al. 1976). The identification of hemoglobin was confirmed using commercial antibodies, which were shown to label a predominant band of $16 \mathrm{kDa}$ in cell lysates prepared from mouse erythrocytes (positive control; Fig. 6A). Figure 6B and $C$ show that the antibodies detected equivalent-sized proteins in QEP recovered from the proximal and distal regions of the ductus epididymidis and resolved by $1 \mathrm{D}$ and 2D SDS-PAGE respectively. The additional spots observed at higher masses $(\sim 48 \mathrm{kDa})$ in the $2 \mathrm{D}$ immunoblot are most likely attributed to incomplete reduction of hemoglobin protein complexes. While the identity of these putative complexes remains to be examined, it is noteworthy that a similar band can also be seen in the $1 \mathrm{D}$ gel of proteins extracted from mouse erythrocytes (Fig. 6A).

\section{Localization of hemoglobin in the quail epididymis}

Having confirmed the specificity of the hemoglobin antibodies, they were used to localize the protein in sections of the quail epididymis. A consistent labeling pattern for hemoglobin was observed throughout the ductus epididymidis including a modest amount of punctate labeling in the apical region of the duct epithelium (Fig. 7). However, the epithelial labeling decreased distally along the duct and was virtually absent in the mid and distal region of the duct. By contrast, the lumen was strongly labeled in all regions of the ductus epididymidis and appeared to increase from the proximal to distal regions. Counterstaining of cell nuclei with propidium iodide revealed that, although hemoglobin was closely opposed to sperm within the luminal environment, it did not appear to co-localize with these cells. The specificity of these findings was confirmed by the lack of staining observed in negative control treatments in which the primary antibody was omitted.

Given the novelty of these findings, and that hemoglobin had been identified in the epididymal proteome of bulls (Belleannee et al. 2011) and rabbits (Reddy et al. 2011), we sought to extend our analysis to compare the distribution of hemoglobin in the quail epididymis with that in the epididymis of a mammal. Figure 8 shows that the distribution of hemoglobin in the mouse epididymis is very different from that observed in the quail epididymis. In mice, hemoglobin appeared to cluster in a discrete zone located within the apical region of the principal cells. This intense labeling was similar in both the caput and corpus epididymidis, but it was absent in the cauda epididymidis. Furthermore, in contrast to the quail, hemoglobin was not detected at appreciable levels within the lumen in any region of the ductus epididymidis. This result was supported by immunoblotting analyses, which also revealed that hemoglobin was not detectable in luminal fluid sampled from different regions of the mouse epididymis (results not shown). On the basis 


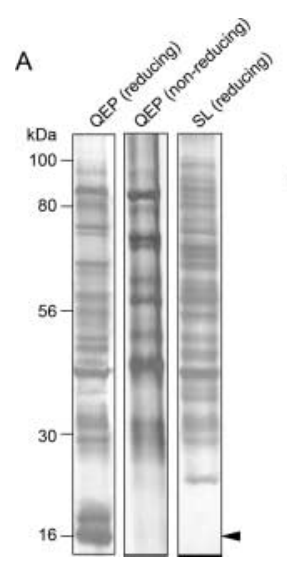

B

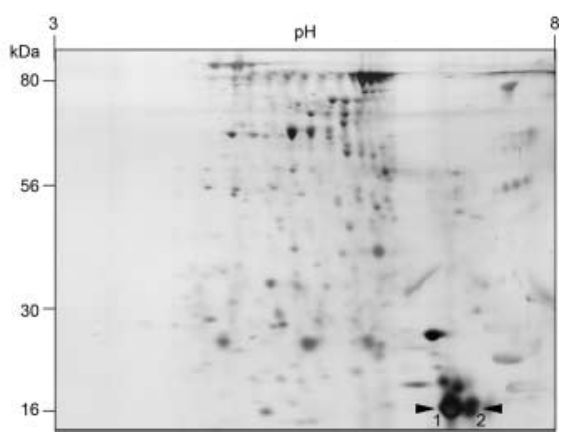

Figure 5 Resolution of quail epididymal fluid and sperm proteins. (A) 1D SDS-PAGE electrophoretic profile of QEP and sperm lysates (SL) resolved under reducing and non-reducing conditions. (B) In preparation for ESI-MS/MS sequencing analysis, the proteins present in quail epididymal luminal fluid were also resolved by 2D SDS-PAGE. Arrowheads indicate the $16 \mathrm{kDa}$ protein that was targeted for sequencing analysis. Note that this protein was not detected in epididymal fluid resolved under non-reducing conditions and does not appear to interact directly with quail epididymal spermatozoa. All experiments were replicated with samples from five quails and representative gels are shown.

of these results, we infer that hemoglobin fulfills different roles in the quail and mouse epididymides.

\section{Discussion}

This study addressed the contribution of the epididymis to the attainment of functional maturity of Japanese quail spermatozoa. In contrast to their mammalian counterparts, where it is well established that spermatozoa undergo a number of important changes in the epididymis, we found few changes in the functional profile of quail spermatozoa within the epididymis. These results are in keeping with the fundamental differences in the anatomy and biology of the avian and mammalian reproductive systems (Jones et al. 2003). Indeed, the ductus epididymides of the Galliformes that have been studied are relatively short by comparison with that of mammals, lined by a nonciliated epithelium, and structurally similar throughout their length (Lake 1957, Tingari 1971, 1972, 1973, Aire 1979a, 1979b, 1980, Clulow \& Jones 1988). This lack of structural differentiation is also reflected in the profile of proteins recovered from the epididymal lumen. Apparently, they mainly originate from the seminiferous tubules and the proteome is not overtly modified in any region of the ductus epididymides except for the addition of one predominant $16 \mathrm{kDa}$ protein (Fig. 4), hemoglobin, the secretion of which is dependent on the testis. This finding is consistent with the fact that avian testicular fluid and spermatozoa are produced in large quantities (Clulow \& Jones 1982, 1988, Aire \& Ozegbe 2007) and pass through the excurrent ducts extremely rapidly (only 1-2 days in the quail and fowl) (Amir et al. 1973, Clulow \& Jones 1982). Such rapid transit satisfies the requirements of the competitive mating system that exists in most avian species (Birkhead \& Moller 1993, Jones \& Lin 1993) but imposes limitations on the amount of posttesticular maturation that the spermatozoa can undergo. This is further exacerbated by the inability of the avian male to store sperm prior to ejaculation, a function that has instead been transferred to the female (Holm et al. 1996, 2000).

As in other avian species, the maturational process that does occur in the quail epididymis is manifested in the ability to display progressive motility. The importance of motility is evidenced by the fact that avian spermatozoa encounter an intense selection pressure in the vaginal region of the oviduct and poorly motile cells are incapable of traversing the vagina to reach the infundibulum (Allen \& Grigg 1957). The finding in this study that a significant proportion of testicular sperm

Table 1 Identification of the $16 \mathrm{kDa}$ protein detected within the Japanese quail epididymis.

\begin{tabular}{|c|c|c|c|c|}
\hline Accession number & Protein (symbol) & $\mathbf{M W}(\mathrm{kDa})$ & $\begin{array}{l}\text { No. of matching } \\
\text { peptides identified }\end{array}$ & $\begin{array}{c}\text { Overall } \\
\text { MASCOT score } \\
\end{array}$ \\
\hline \multicolumn{5}{|l|}{$B A N D 1^{\mathrm{a}}$} \\
\hline P24589 & Hemoglobin $\alpha 1$ (HBAA) & 15308 & 7 & 911 \\
\hline AAB26219 & Hemoglobin $\alpha 2$ (HBAD) & 15566 & 5 & 556 \\
\hline AAB26218 & Hemoglobin $\beta$ (HBB) & 16325 & 8 & 554 \\
\hline \multicolumn{5}{|l|}{$S P O T 1^{\mathrm{a}}$} \\
\hline P24589 & Hemoglobin, $\alpha 1$ (HBAA) & 15308 & 8 & 436 \\
\hline AAB26218 & Hemoglobin $\beta$ (HBB) & 16325 & 6 & 264 \\
\hline AAB26219 & Hemoglobin, $\alpha 2$ (HBAD) & 15566 & 5 & 254 \\
\hline \multicolumn{5}{|l|}{ SPOT $2^{\mathrm{a}}$} \\
\hline AAB26218 & Hemoglobin $\beta$ (HBB) & 16325 & 7 & 380 \\
\hline P24589 & Hemoglobin, $\alpha 1$ (HBAA) & 15308 & 5 & 274 \\
\hline AAB26219 & Hemoglobin, $\alpha 2$ (HBAD) & 15566 & 4 & 185 \\
\hline
\end{tabular}

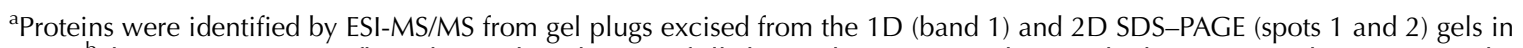
Fig. 5. ${ }^{\text {b }}$ The MASCOT score reflects the combined scores of all observed mass spectra that matched to amino acid sequences within each protein (www.matrixscience.com). 


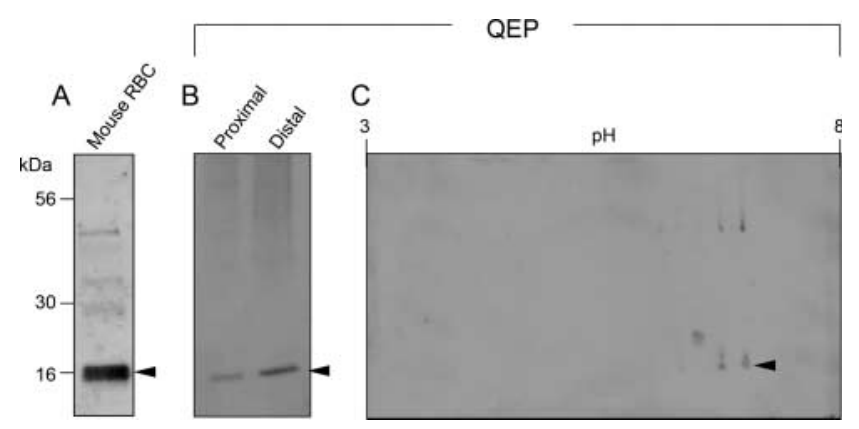

Figure 6 Confirmation of the presence of hemoglobin in QEP. (A) The specificity of anti-hemoglobin antibodies was validated against cell lysates prepared from mouse erythrocytes (mouse RBC). These antibodies were then used to confirm the expression of hemoglobin within quail epididymal plasma (QEP) sampled from (B) the proximal and distal regions of the duct by immunoblotting of 1D or (C) 2D SDSPAGE gels. Arrowheads indicate the predominant $16 \mathrm{kDa}$ that, as anticipated, was detected in mouse erythrocytes. A similar band was also detected in QEP resolved by 1D SDS-PAGE, and, as expected, this protein was separated into two charge variants by 2D SDS-PAGE.

displays forward motility (i.e. as fast as sperm from the distal ductus epididymidis) and can bind to the PVM and acrosome react explains the earlier findings of Munro (1938) who achieved some fertilizations following vaginal insemination of testicular fowl sperm. It also explains why Howarth (1983) obtained a high rate of fertilizations following intramagnal insemination of testicular sperm. Nevertheless, the evidence in this and previous reports show that Galliformes sperm undergo some post-testicular sperm maturation, which involves an increase in the proportion of sperm that acquire sufficient motility to achieve fertilization following natural mating. However, it is uncertain whether this maturation is an intrinsic or extrinsic process: the success that Howarth (1983) achieved with intramagnal inseminations indicates that an epididymal environment is not essential for post-testicular sperm maturation at least when artificial insemination is used.

The physiological mechanisms that underpin the functional maturation of avian sperm have yet to be resolved. It has been shown that non-passerine sperm do not undergo substantive changes in their morphology during epididymal transit (Tingari 1973). Also, due to the form of spermiation in birds (Lin \& Jones 1993), there is no cytoplasmic droplet to migrate along the middle piece as in mammalian sperm. However, work on the domestic fowl has shown that a subset of the proteins that sperm encounter during their epididymal passage bind to their surface (Esponda \& Bedford 1985) and remain adherent even after prolonged incubation within the female reproductive tract (Morris et al. 1987). While the identity of these proteins remains to be established, they appear specific to Galliform birds and antibodies to them cross-react with quail spermatozoa (Esponda \& Bedford 1985, Morris et al. 1987). The binding of these proteins to the surface of sperm shares some analogy with the epididymal-driven modification of mammalian spermatozoa (Orgebin-Crist 1973, Orgebin-Crist \& Jahad 1978, Nixon et al. 2002b).

These studies (Figs 2 and 3) support earlier work (Howarth 1970, Olszanska et al. 2002) that concluded that avian spermatozoa do not require a period of capacitation. Indeed, we have demonstrated that the potential to undergo tyrosine phosphorylation, one of the key hallmarks of the capacitation process in mammals, is not overtly influenced by epididymal transit in the quail (Fig. 2). Similarly, although we were able to
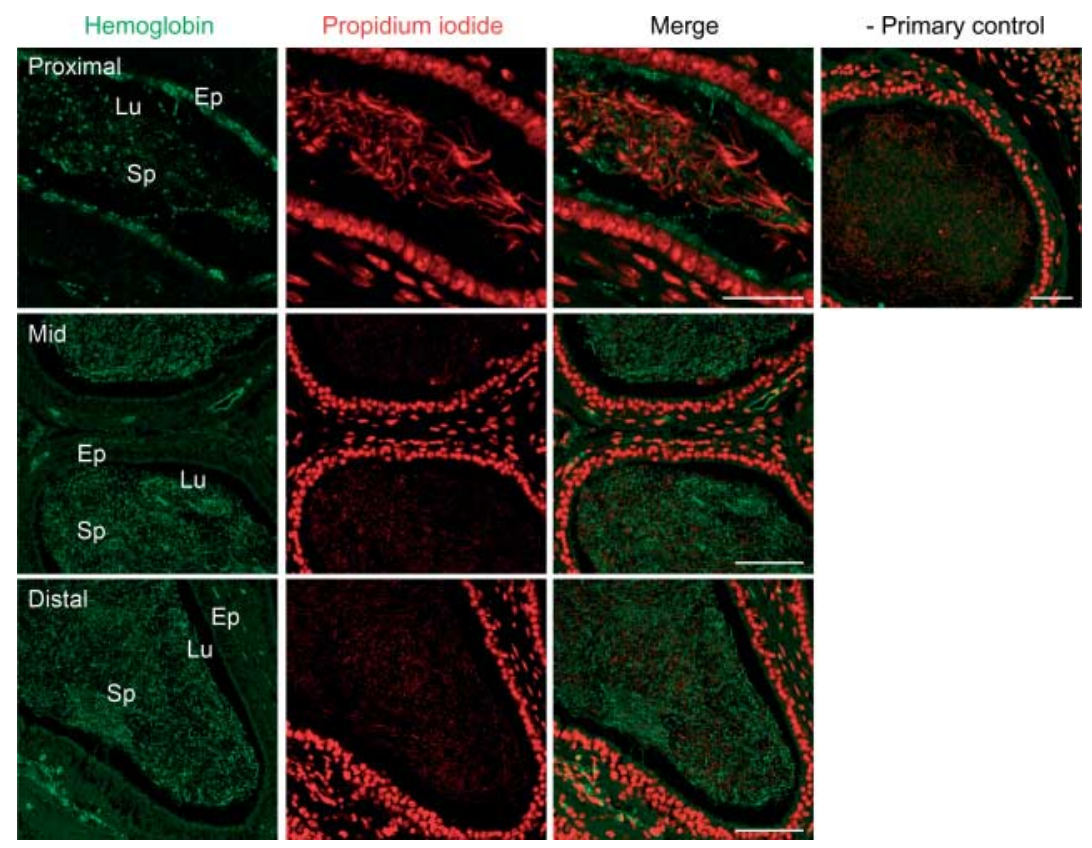

www.reproduction-online.org
Figure 7 Examination of the localization of hemoglobin in the quail epididymis. Formalinfixed tissue from the proximal, mid, and distal regions of the quail epididymis were sequentially labeled with anti-hemoglobin and an appropriate FITC-conjugated secondary antibody. The sections were counterstained with the nuclear dye, propidium iodide, before being mounted in antifade reagent, and viewed using a confocal microscope. Hemoglobin localized primarily to the lumen (Lu) but was also detected in the apical region of proximal epididymal epithelium (Ep). Although hemoglobin appeared in close proximity to spermatozoa (Sp) within the lumen of all epididymidis regions examined, it consistently failed to co-localize with these cells. No staining was observed in the negative control prepared in the absence of primary antibody (-Primary control). Scale bar $=20 \mu \mathrm{m}$. 


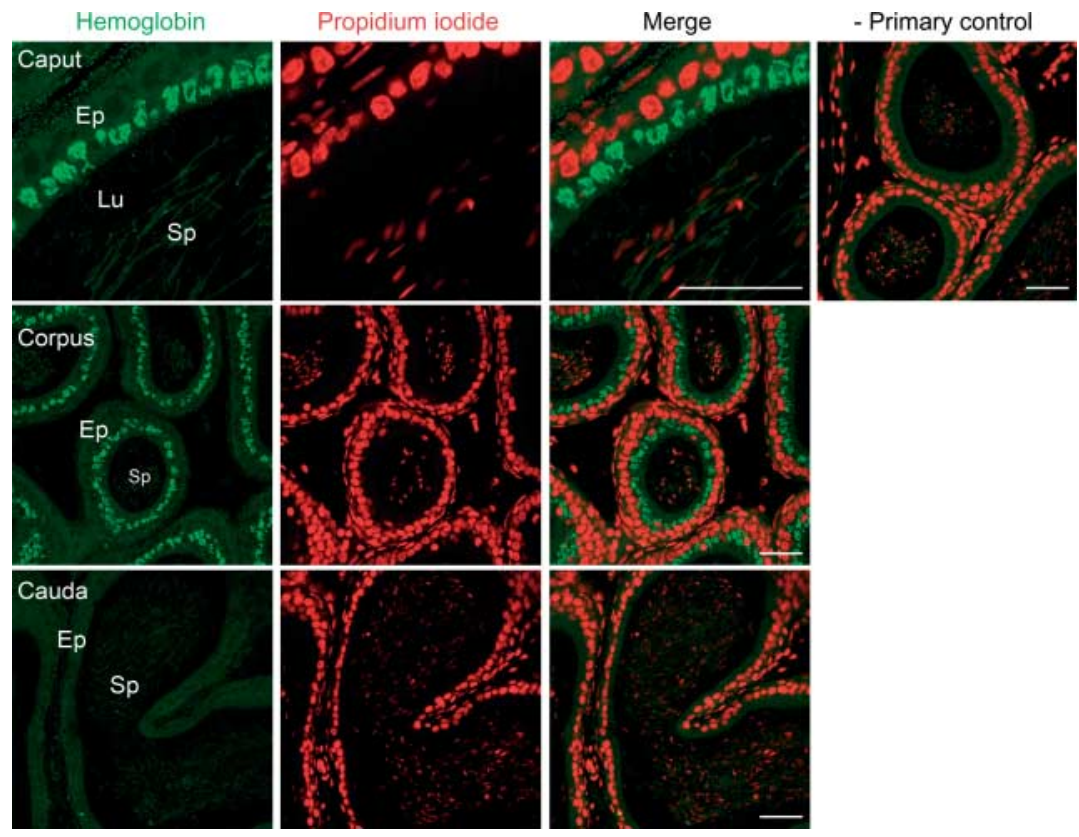

Figure 8 Examination of the localization of hemoglobin in the mouse epididymis. Formalinfixed tissue from the caput, corpus, and caudal regions of the mouse epididymis were sequentially labeled with anti-hemoglobin and an appropriate FITC-conjugated secondary antibody. The sections were counterstained with the nuclear dye, propidium iodide, before being mounted in antifade reagent, and viewed using a confocal microscope. Hemoglobin localized primarily to the apical region of caput and corpus epididymal epithelium (Ep) but could not be detected in similar cells within the cauda epididymidis. Similarly, hemoglobin was not detected within the lumen of any epididymal region examined. No staining was observed in the negative control prepared in the absence of primary antibody (-Primary control). Scale bar $=20 \mu \mathrm{m}$. detect basal levels of tyrosine phosphorylation by immunoblotting, the manipulation of the capacitation conditions did not induce any global changes in the qualitative profile or relative amount of phosphotyrosine detected. While we acknowledge that these studies were limited to conditions that have been optimized for mammalian spermatozoa (Nixon et al. 2006), and do not preclude the possibility of serine or threonine phosphorylation, they nevertheless suggest that quail spermatozoa cannot be 'driven' to exhibit correlates of capacitation under conditions that mimic those of mammalian spermatozoa. Instead, it appears likely that any epididymal components acquired by fowl spermatozoa may influence other functions such as sperm transport, storage, and/or survival in the female.

In contrast to the work of Bedford et al. (Esponda \& Bedford 1985, Morris et al. 1987), we were only able to detect a single major secretory product in the quail epididymis and this protein was identified as hemoglobin. Our studies demonstrated that hemoglobin is secreted in the proximal ductus epididymidis (Fig. 4) and concentrated in the lumen of the duct, where it is in close apposition with spermatozoa (Fig. 7). This report of hemoglobin within the epididymis adds to a growing list of tissues, beyond those of the erythroid lineage, in which the protein is putatively expressed (Mansergh et al. 2008, Nishi et al. 2008, Richter et al. 2009, Liu et al. 2011). As many of these tissues lack oxygenbinding capacity, it is suggested that hemoglobin has novel physiological roles including important contributions to redox equilibrium processes (Reischl et al. 2007). Such redox buffering activity is attributed to the presence of a number of externally positioned, reactive cysteines that are capable of undergoing reversible glutathiolation after oxidative challenge (Reischl \& Dafre 1992, Dafre \& Reischl 1998, 2006, Reischl et al. 2007). These findings raise the possibility that hemoglobin may act as an additional line of antioxidant defense, beyond that of the classical antioxidant enzymes that have evolved to help protect spermatozoa from oxidative stress during this highly vulnerable phase of their development (Vernet et al. 2004).

While further work is required to define the antioxidant activity of hemoglobin within the quail epididymis, an alternative function is suggested by the protein's appearance in the lumen coinciding with the acquisition of sperm motility. This raises the possibility that hemoglobin may be necessary for supporting the metabolic demands imposed by the onset of motility. In support of this interpretation, it has previously been shown that the motility of quail spermatozoa is rapidly depressed in the event of delayed release from the epididymal duct following killing (Clulow \& Jones 1982). Furthermore, it is known that Japanese quail spermatozoa are heavily reliant on oxidative phosphorylation to support their motility. Indeed, a defining characteristic of these cells is that they possess an exceptionally elongated midpiece $(160-170 \mu \mathrm{m})$ that accounts for between 64 and $74 \%$ of the overall length of the cell (Korn et al. 2000). This remarkable structure houses in excess of 1400 mitochondria per sperm, far exceeding the 20-30 mitochondria typically found in other Galliformes such as the turkey and chicken (Thurston \& Hess 1987). In addition, it also exceeds the description of sperm from the common quail (Coturnix coturnix) with a reported midpiece length of $\sim 110 \mu \mathrm{m}$ and estimated number of mitochondria of 350 per sperm (Saita et al. 1980). While the adaptive 
significance of this structural variation is largely unknown, the comparatively high numbers of mitochondria found in quail spermatozoa suggest the requirement for oxidative phosphorylation to supply the demands of ATP generation (Korn et al. 2000). In other Galliformes, it is known that sperm oxygen consumption and ATP levels both directly correlated with fertilizing capacity (Wishart 1982, Froman \& Feltmann 1998). This ATP is presumably directed to the support of sperm motility as the oxygen consumption among sperm from male domestic fowl with a high mobility phenotype has been estimated as being twice that of sperm from males with average mobility (Froman \& Feltmann 1998).

If the role of epididymal hemoglobin is indeed to supply oxygen to support sperm respiration and hence motility, then one may expect that there should be differential expression of hemoglobin within the epididymal environment depending on the extent to which spermatozoa utilize oxidative phosphorylation. Preliminary evidence in support of this conclusion was provided by the demonstration that, although hemoglobin was strongly labeled within the epididymal epithelium, it could not be detected at appreciable concentrations within the epididymal lumen of the mouse, a species whose sperm function effectively on glycolysis without the need for additional mitochondrial energy production (Bedford \& Hoskins 1990). However, it should be noted that hemoglobin has also recently been identified as a secretory product of the rabbit epididymis (Reddy et al. 2011), a species in which glycolysis is sufficient to maintain sperm motility (Storey $1975,2008)$. Nevertheless, the authors of this study demonstrated that hemoglobin bound to the acrosome of ejaculated spermatozoa and concluded that it was likely to be acting as an antimicrobial peptide involved in the modulation of immune responses against invading pathogens (Reddy et al. 2011). Given that no such interaction was observed between quail spermatozoa and hemoglobin in this study, it is considered likely that the protein may fulfill a different role in these species.

Taken together, our data support the notion that the process of post-testicular sperm maturation is far less complex in the avian system than that documented in mammals. However, we did note a gradient of motility that increased upon entry into the epididymal environment. Our investigation of the changes in the epididymal environment associated with the acquisition of motility revealed the presence of a single predominant protein that was identified as hemoglobin. While further work is necessary to definitively characterize the role of this protein, such results raise the intriguing possibility that hemoglobin may be secreted into the quail epididymis to support sperm metabolism, aid in motility, and/or act as an antioxidant. Given the metabolic specialization observed among vertebrate spermatozoa, it will be of considerable interest to investigate the implications of these findings in a wider variety of species. Such studies may ultimately provide information on determinants of fertilizing capacity that could inform the development of sperm storage procedures that would prevent the loss of fertilizing capacity.

\section{Declaration of interest}

The authors declare that there is no conflict of interest that could be perceived as prejudicing the impartiality of the research reported.

\section{Funding}

This work was supported by the Australian Research Council (grant number DP1092849).

\section{Acknowledgements}

The authors acknowledge the excellent technical assistance of Amanda Beilanowicz in the collection of the data presented herein.

\section{References}

Ahammad MU, Nishino C, Tatemoto H, Okura N, Kawamoto Y, Okamoto S \& Nakada T 2011a Maturational changes in motility, acrosomal proteolytic activity, and penetrability of the inner perivitelline layer of fowl sperm, during their passage through the male genital tract. Theriogenology $\mathbf{7 6}$ 1100-1109. (doi:10.1016/j.theriogenology.2011.05.017)

Ahammad MU, Nishino C, Tatemoto H, Okura N, Kawamoto Y, Okamoto S \& Nakada T $2011 b$ Maturational changes in the survivability and fertility of fowl sperm during their passage through the male reproductive tract. Animal Reproduction Science 128 129-136. (doi:10.1016/j.anireprosci. 2011.09.010)

Aire TA 1979a The epididymal region of the Japanese quail (Coturnix coturnix japonica). Acta Anatomica 103 305-312. (doi:10.1159/000145028)

Aire TA $1979 b$ Micro-stereological study of the avian epididymal region. Journal of Anatomy 129 703-706.

Aire TA 1980 The ductuli efferentes of the epididymal region of birds. Journal of Anatomy 130 707-723.

Aire TA \& Ozegbe PC 2007 The testicular capsule and peritubular tissue of birds: morphometry, histology, ultrastructure and immunohistochemistry. Journal of Anatomy 210 731-740. (doi:10.1111/j.1469-7580.2007. 00726.x)

Allen TE \& Grigg GW 1957 Sperm transport in the fowl. Australian Journal of Agricultural Research 8 788-789. (doi:10.1071/AR9570788)

Amir D, Braun-Eilon B \& Schindler H 1973 Passage and disappearance of labelled spermatozoa in the genital tract of the male Japanese quail in segregation or cohabitation. Annales de Biologie Animale, Biochimie, Biophysique 13 321-328. (doi:10.1051/rnd:19730302)

Asquith KL, Baleato RM, McLaughlin EA, Nixon B \& Aitken RJ 2004 Tyrosine phosphorylation activates surface chaperones facilitating sperm-zona recognition. Journal of Cell Science 117 3645-3657. (doi:10.1242/jcs.01214)

Austin CR 1951 Observations on the penetration of the sperm in the mammalian egg. Australian Journal of Scientific Research. Series B: Biological Sciences 4 581-596.

Bedford JM 1967 Effects of duct ligation on the fertilizing ability of spermatozoa from different regions of the rabbit epididymis. Journal of Experimental Zoology 166 271-281. (doi:10.1002/jez.1401660210)

Bedford JM \& Hoskins DD 1990 The mammalian spermatozoon: morphology, biochemistry and physiology. In Marshall's Physiology of Reproduction, pp 379-568. ED G E Lemming, London: Churchill Livingstone. 
Belleannee C, Labas V, Teixeira-Gomes AP, Gatti JL, Dacheux JL \& Dacheux F 2011 Identification of luminal and secreted proteins in bull epididymis. Journal of Proteomics 74 59-78. (doi:10.1016/j.jprot.2010.07.013)

Biggers JD, Whitten WK \& Whittingham DG 1971 The culture of mouse embryos in vitro. In Methods in Mammalian Embryology, pp 86-116.

Birkhead T \& Moller A 1993 Female control of paternity. Trends in Ecology \& Evolution 8 100-104. (doi:10.1016/0169-5347(93)90060-3)

Bradford MM 1976 A rapid and sensitive method for the quantitation of microgram quantities of protein utilizing the principle of protein-dye binding. Analytical Biochemistry 72 248-254. (doi:10.1016/00032697(76)90527-3)

Chang MC 1951 Fertilizing capacity of spermatozoa deposited into the fallopian tubes. Nature 168 697-698. (doi:10.1038/168697b0)

Clulow J \& Jones RC 1982 Production, transport, maturation, storage and survival of spermatozoa in the male Japanese quail, Coturnix coturnix. Journal of Reproduction and Fertility 64 259-266. (doi:10.1530/jrf.0. 0640259)

Clulow J \& Jones RC 1988 Studies of fluid and spermatozoal transport in the extratesticular genital ducts of the Japanese quail. Journal of Anatomy $1571-11$.

Clulow J \& Jones RC 2004 Composition of luminal fluid secreted by the seminiferous tubules and after reabsorption by the extratesticular ducts of the Japanese quail, Coturnix coturnix japonica. Biology of Reproduction 71 1508-1516. (doi:10.1095/biolreprod.104.031401)

Dacheux JL, Belleannee C, Jones R, Labas V, Belghazi M, Guyonnet B, Druart X, Gatti JL \& Dacheux F 2009 Mammalian epididymal proteome. Molecular and Cellular Endocrinology 306 45-50. (doi:10.1016/j.mce. 2009.03.007)

Dacheux JL, Belleannee C, Guyonnet B, Labas V, Teixeira-Gomes AP, Ecroyd H, Druart X, Gatti JL \& Dacheux F 2012 The contribution of proteomics to understanding epididymal maturation of mammalian spermatozoa. Systems Biology in Reproductive Medicine 58 197-210. (doi:10.3109/19396368.2012.663233)

Dafre AL \& Reischl E 1998 Oxidative stress causes intracellular reversible S-thiolation of chicken hemoglobin under diamide and xanthine oxidase treatment. Archives of Biochemistry and Biophysics 358 291-296. (doi:10.1006/abbi.1998.0848)

Dafre AL \& Reischl E 2006 Hemoglobin S-thiolation during peroxideinduced oxidative stress in chicken blood. Comparative Biochemistry and Physiology. Toxicology \& Pharmacology 142 188-197. (doi:10.1016/ j.cbpc.2005.09.005)

Davis BK 1981 Timing of fertilization in mammals: sperm cholesterol/ phospholipid ratio as a determinant of the capacitation interval. PNAS 78 7560-7564. (doi:10.1073/pnas.78.12.7560)

Davis BK, Byrne R \& Hungund B 1979 Studies on the mechanism of capacitation. II. Evidence for lipid transfer between plasma membrane of rat sperm and serum albumin during capacitation in vitro. Biochimica et Biophysica Acta 558 257-266. (doi:10.1016/0005-2736(79)90260-8)

Esponda P \& Bedford JM 1985 Surface of the rooster spermatozoon changes in passing through the Wolffian duct. Journal of Experimental Zoology 234 441-449. (doi:10.1002/jez.1402340311)

Fraser LR, Harrison RA \& Herod JE 1990 Characterization of a decapacitation factor associated with epididymal mouse spermatozoa. Journal of Reproduction and Fertility 89 135-148. (doi:10.1530/jrf.0. 0890135)

Froman DP \& Feltmann AJ 1998 Sperm mobility: a quantitative trait of the domestic fowl (Gallus domesticus). Biology of Reproduction $\mathbf{5 8}$ 379-384. (doi:10.1095/biolreprod58.2.379)

Gibbons R, Adeoya-Osiguwa SA \& Fraser LR 2005 A mouse sperm decapacitation factor receptor is phosphatidylethanolamine-binding protein 1. Reproduction 130 497-508. (doi:10.1530/rep.1.00792)

Holm L, Ridderstrale Y \& Knutsson PG 1996 Localisation of carbonic anhydrase in the sperm storing regions of the domestic hen oviduct. Acta Anatomica 156 253-260. (doi:10.1159/000147853)

Holm L, Ekwall H, Wishart GJ \& Ridderstrale Y 2000 Localization of calcium and zinc in the sperm storage tubules of chicken, quail and turkey using X-ray microanalysis. Journal of Reproduction and Fertility 118 331-336. (doi:10.1530/jrf.0.180331)

Horrocks AJ, Stewart S, Jackson L \& Wishart G) 2000 Induction of acrosomal exocytosis in chicken spermatozoa by inner perivitellinederived N-linked glycans. Biochemical and Biophysical Research Communications 278 84-89. (doi:10.1006/bbrc.2000.3766)
Howarth B Jr 1970 An examination for sperm capacitation in the fowl. Biology of Reproduction 3 338-341.

Howarth B Jr 1983 Fertilizing ability of cock spermatozoa from the testis epididymis and vas deferens following intramagnal insemination. Biology of Reproduction 28 586-590. (doi:10.1095/biolreprod28.3.586)

Howarth B Jr \& Palmer MB 1972 An examination of the need for sperm capacitation in the turkey, Meleagris gallopavo. Journal of Reproduction and Fertility 28 443-445. (doi:10.1530/jrf.0.0280443)

Jones R 1989 Membrane remodelling during sperm maturation in the epididymis. Oxford Reviews of Reproductive Biology 11 285-337.

Jones R 1998 Plasma membrane structure and remodelling during sperm maturation in the epididymis. Journal of Reproduction and Fertility. Supplement 53 73-84.

Jones RC \& Lin M 1993 Spermatogenesis in birds. Oxford Reviews of Reproductive Biology 15 233-264.

Jones RC \& Murdoch RN 1996 Regulation of the motility and metabolism of spermatozoa for storage in the epididymis of eutherian and marsupial mammals. Reproduction, Fertility, and Development 8 553-568. (doi:10.1071/RD9960553)

Jones RC, Clulow J, Kidd G, Chaturapanich G, Nixon B \& Dacheux J-L 2003 The avian epididymis: a simple conduit or a sophisticated adaptation? In The Third International Conference on the Epididymis, pp 138-148. Eds B T Hinton and TT Turner, Charlottesville, VA, USA: The van Doren Co.

Korn N, Thurston RJ, Pooser BP \& Scott TR 2000 Ultrastructure of spermatozoa from Japanese quail. Poultry Science 79 86-93.

Kuroki M \& Mori M 1995 Origin of $33 \mathrm{kDa}$ protein of the vitelline membrane of quail egg: immunological studies. Development, Growth \& Differentiation 37 545-550. (doi:10.1046/j.1440-169X. 1995.t01-4-00009.x)

Laemmli UK 1970 Cleavage of structural proteins during the assembly of the head of bacteriophage T4. Nature 227 680-685. (doi:10.1038/227680a0)

Lake PE 1957 The male reproductive tract of the fowl. Journal of Anatomy 91 116-129.

Lee KS, Huang PC \& Cohen BH 1976 Further resolution of adult chick hemoglobins by isoelectric focusing in polyacrylamide gel. Biochimica et Biophysica Acta 427 178-196. (doi:10.1016/0005-2795 (76)90295-6)

Lemoine M, Grasseau I, Brillard JP \& Blesbois E 2008 A reappraisal of the factors involved in in vitro initiation of the acrosome reaction in chicken spermatozoa. Reproduction 136 391-399. (doi:10.1530/REP-08-0094)

Lemoine M, Dupont J, Guillory V, Tesseraud S \& Blesbois E 2009 Potential involvement of several signaling pathways in initiation of the chicken acrosome reaction. Biology of Reproduction 81 657-665. (doi:10.1095/ biolreprod.108.072660)

Lin M \& Jones RC 1993 Spermiogenesis and spermiation in the Japanese quail (Coturnix coturnix japonica). Journal of Anatomy 183 525-535.

Liu W, Baker SS, Baker RD, Nowak NJ \& Zhu L 2011 Upregulation of hemoglobin expression by oxidative stress in hepatocytes and its implication in nonalcoholic steatohepatitis. PLOS ONE 6 e24363. (doi:10.1371/journal.pone.0024363)

Mansergh FC, Hunter SM, Geatrell JC, Jarrin M, Powell K, Evans MJ \& Wride MA 2008 Developmentally regulated expression of hemoglobin subunits in avascular tissues. International Journal of Developmental Biology 52 873-886. (doi:10.1387/ijdb.082597fm)

Mori M \& Kantou T 1987 Changes in progesterone production in granulosa cells during the ovulatory cycle of the Japanese quail (Coturnix coturnix japonica). General \& Comparative Endocrinology 68 57-63. (doi:10. 1016/0016-6480(87)90060-8)

Morris SA, Howarth B Jr, Crim JW, Rodriguez de Cordoba A, Esponda P \& Bedford JM 1987 Specificity of sperm-binding Wolffian duct proteins in the rooster and their persistence on spermatozoa in the female host glands. Journal of Experimental Zoology 242 189-198. (doi:10.1002/ jez.1402420210)

Morton BE, Sagadraca R \& Fraser C 1978 Sperm motility within the mammalian epididymis: species variation and correlation with free calcium levels in epididymal plasma. Fertility and Sterility 29 695-698.

Munro SS 1938 Functional changes in fowl sperm during their passage through the excurrent ducts of the male. Journal of Experimental Zoology 79 71-92. (doi:10.1002/jez.1400790106) 
Nishi H, Inagi R, Kato H, Tanemoto M, Kojima I, Son D, Fujita T \& Nangaku M 2008 Hemoglobin is expressed by mesangial cells and reduces oxidant stress. Journal of the American Society of Nephrology 19 1500-1508. (doi:10.1681/ASN.2007101085)

Nixon B, Jones RC, Clarke HG \& Holland MK 2002a Rabbit epididymal secretory proteins. II. Immunolocalization and sperm association of REP38. Biology of Reproduction 67 140-146. (doi:10.1095/ biolreprod67.1.140)

Nixon B, Jones RC, Hansen LA \& Holland MK 2002b Rabbit epididymal secretory proteins. I. Characterization and hormonal regulation. Biology of Reproduction 67 133-139. (doi:10.1095/biolreprod67.1.133)

Nixon B, MacIntyre DA, Mitchell LA, Gibbs GM, O'Bryan M \& Aitken RJ 2006 The identification of mouse sperm-surface-associated proteins and characterization of their ability to act as decapacitation factors. Biology of Reproduction 74 275-287. (doi:10.1095/biolreprod.105. 044644)

Olszanska B, Stepinska U \& Perry MM 2002 Development of embryos from in vitro ovulated and fertilized oocytes of the quail (Coturnix coturnix japonica). Journal of Experimental Zoology 292 580-586. (doi:10.1002/ jez.10096)

Orgebin-Crist MC 1967 Sperm maturation in rabbit epididymis. Nature 216 816-818. (doi:10.1038/216816a0)

Orgebin-Crist MC 1973 Maturation of spermatozoa in the rabbit epididymis: effect of castration and testosterone replacement. Journal of Experimental Zoology 185 301-310. (doi:10.1002/jez.1401850304)

Orgebin-Crist MC \& Jahad N 1978 The maturation of rabbit epididymal spermatozoa in organ culture: inhibition by antiandrogens and inhibitors of ribonucleic acid and protein synthesis. Endocrinology 103 46-53. (doi:10.1210/endo-103-1-46)

Rankin TL, Tsuruta KJ, Holland MK, Griswold MD \& Orgebin-Crist MC 1992 Isolation, immunolocalization, and sperm-association of three proteins of 18,25, and 29 kilodaltons secreted by the mouse epididymis. Biology of Reproduction 46 747-766. (doi:10.1095/biolreprod46.5.747)

Reddy KVR, Deva S, Aranha C, Patgaonkar MS \& Bhonde G 2011 Identification and characterization of molecules having anti-microbial activities from rabbit epididymis using proteomic approach. International Journal of Microbial \& Biochemical Technology S2 002.

Reischl E \& Dafre AL 1992 Glutathione mixed disulfides and heterogeneity of chicken hemoglobins. Comparative Biochemistry and Physiology. B, Comparative Biochemistry 102 849-853. (doi:10.1016/03050491(92)90091-5)

Reischl E, Dafre AL, Franco JL \& Wilhelm Filho D 2007 Distribution, adaptation and physiological meaning of thiols from vertebrate hemoglobins. Comparative Biochemistry and Physiology. Toxicology \& Pharmacology 146 22-53. (doi:10.1016/j.cbpc.2006.07.015)

Richter F, Meurers BH, Zhu C, Medvedeva VP \& Chesselet MF 2009 Neurons express hemoglobin $\alpha$ - and $\beta$-chains in rat and human brains. Journal of Comparative Neurology 515 538-547. (doi:10.1002/cne. 22062)
Saita A, Tripepi S \& Longo M 1980 Osservazioni comparative sulla spermiogenesi. I. Modificazioni ultrastrutturali nella spermiogenesi de Coturnix coturnix. Academia Nazionale dei Lincei 69 209-216.

Sonnenberg-Riethmacher E, Walter B, Riethmacher D, Godecke S \& Birchmeier C 1996 The c-ros tyrosine kinase receptor controls regionalization and differentiation of epithelial cells in the epididymis. Genes and Development 10 1184-1193. (doi:10.1101/gad.10.10.1184)

Storey BT 1975 Energy metabolism of spermatozoa. IV. Effect of calcium on respiration of mature epididymal sperm of the rabbit. Biology of Reproduction 13 1-9. (doi:10.1095/biolreprod13.1.1)

Storey BT 2008 Mammalian sperm metabolism: oxygen and sugar, friend and foe. International Journal of Developmental Biology 52 427-437. (doi:10.1387/ijdb.072522bs)

Thurston RJ \& Hess RA 1987 Ultrastructure of spermatozoa from domesticated birds: comparative study of turkey, chicken and guinea fowl. Scanning Microscopy 1 1829-1838.

Tingari MD 1971 On the structure of the epididymal region and ductus deferens of the domestic fowl (Gallus domesticus). Journal of Anatomy $109423-435$.

Tingari MD 1972 The fine structure of the epithelial lining of the ex-current duct system of the testis of the domestic fowl (Gallus domesticus). Quarterly Journal of Experimental Physiology and Cognate Medical Sciences 57 271-295.

Tingari MD 1973 Observations on the fine structure of spermatozoa in the testis and excurrent ducts of the male fowl, Gallus domesticus. Journal of Reproduction and Fertility 34 255-265. (doi:10.1530/jrf.0.0340255)

Towbin H, Staehelin T \& Gordon J 1979 Electrophoretic transfer of proteins from polyacrylamide gels to nitrocellulose sheets: procedure and some applications. PNAS 76 4350-4354. (doi:10.1073/pnas.76.9.4350)

Vernet P, Aitken RJ \& Drevet JR 2004 Antioxidant strategies in the epididymis. Molecular and Cellular Endocrinology $216 \quad 31-39$. (doi:10.1016/j.mce.2003.10.069)

Visconti PE, Bailey JL, Moore GD, Pan D, Olds-Clarke P \& Kopf GS 1995a Capacitation of mouse spermatozoa. I. Correlation between the capacitation state and protein tyrosine phosphorylation. Development 121 1129-1137.

Visconti PE, Moore GD, Bailey JL, Leclerc P, Connors SA, Pan D, OldsClarke P \& Kopf GS 1995 b Capacitation of mouse spermatozoa. II. Protein tyrosine phosphorylation and capacitation are regulated by a cAMP-dependent pathway. Development 121 1139-1150.

Wishart GJ 1982 Maintenance of ATP concentrations in and of fertilizing ability of fowl and turkey spermatozoa in vitro. Journal of Reproduction and Fertility 66 457-462. (doi:10.1530/jrf.0.0660457)

Received 6 November 2013

Accepted 2 December 2013 